\title{
Finite Element Analysis of R.C Beams Using Steel Scraps Under Cyclic Loading Using ETABS
}

\author{
T.Subramani ${ }^{1^{*}}$, R.Nashreen ${ }^{2}$ \\ $1^{*}$ Managing Director, Priyanka Associates (Civil Engineers and Valuers), Salem, TamilNadu, India. \\ ${ }^{2}$ Assistant Engineer, RD, Namakkal., TamilNadu, India. \\ *Corresponding author E-mail: tsmcivil2007@gmail.com
}

\begin{abstract}
In the modern trend peoples are looking for alternate material which is cost effective and high stability in while subject to dynamic loading. Considering this as one of the factor in our proposed we choose steel scrap as reinforced material which has high durability and strength. To find out the withstanding capacity of the dynamic loading model the structure using finite element software and analysis to predict the safety of the structure. From the analysis result we conclude for preventive measure of the structural failure and utilization of extra dampers has find out. To validating the result, analytical work is carried out and implemented by using ETAB software.
\end{abstract}

Keywords: Finite Element Analysis, RC Beams, Steel Scraps, Cyclic Loading, ETABS

\section{Introduction}

Hazardous layout and detailing within the joint place jeopardize the whole shape, even supposing other structural participants conform to the design requirements. When you consider that past three decades, substantial studies has been achieved on analyzing the conduct of joints beneath seismic situations thru experimental and analytical research. Various global codes of practices were undergoing periodic revisions to incorporate the studies findings into practice. In RC homes, quantities of columns which might be commonplace to beams at their intersections are referred to as beam-column joints. In view that their constituent materials have limited strengths, the joints have constrained pressure wearing capability.

While forces larger than those are carried out in the course of earthquakes, joints are severely broken. Repairing broken joints is tough, and so the harm should be avoided. As a result, beamcolumn joints should be designed to face up to earthquake outcomes. Underneath earthquake shaking, the beams adjoining a joint are subjected to moments inside the equal (clockwise or counterclockwise).

\section{Methodology}

Fig.1 shows the methodology of this study.

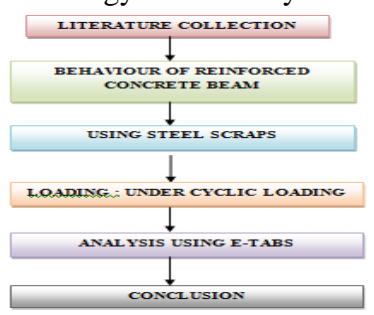

Fig.1: Methodology
Our experiment becomes performed to study the behavior of the SRC beams with various starting shapes underneath blended bending and shear at the region of the outlet. 13 specimens have been designed and fabricated. All of the specimens consisted of the equal amount and association of reinforcement and structural steel form. Specimens were properly instrumented to acquire the worldwide and detailed deformation in the course of the checking out.

\section{Behaviour of Reinforced Concrete Beam}

Beam-column joints in a strengthened concrete moment resisting body are important zones for transfer of loads efficaciously among the connecting elements (i.e. beams and columns) in the shape. Within the analysis of bolstered concrete moment resisting frames, the joints are generally assumed as inflexible hazardous design and detailing inside the joint region jeopardize the entire structure, although different structural individuals comply with the design requirements. On account that beyond three decades, massive research has been done on reading the conduct of joints under seismic conditions thru experimental and analytical studies. Diverse worldwide codes of practices have been present process periodic revisions to incorporate the studies findings into exercise. In RC buildings, portions of columns which might be commonplace to beams at their intersections are called beamcolumn joints. Considering that their constituent materials have limited strengths, the joints have restricted pressure wearing capacity.

\section{Steel Scrap Reinforced Concrete (SSRC)}

Steel scrap reinforced concrete (SSRC) defined as composite substances made with OPC, aggregates and strengthened with steel scrap randomly dispensed fibers or discrete discontinuous fibers. In SFRC, metallic fibers balance the forces with the aid of 
transmitting tensile forces to the steel fibers which run alongside the cracks, as the result flexural durability and flexural energy increases to high-quality amount. SFRC used extensively in types of concrete shape i.e. reinforced concrete structure using metallic bars and non-bolstered structure.

Metal wire is produced via a sequence of hot and bloodless running methods. Round steel fibers are produced by slicing or reducing the cord, usually having diameters within the range of 0.01 to 0.03 inch.6 flat sheet fibers having regular pass sections within the variety 0.0060 to 0.016 inch7 in thickness and 0.0098 to 0.5 inch 8 in width are produced through shearing sheets. fibers have also been made out of hot melt extract. long individual fibers, if no longer brought well by using sifting via a display, have given problem inside the past with the aid of clustering collectively, regularly making uniform distribution inside the matrix difficult.

\section{Cyclic Loading}

A number of the beam-column joint, outdoors joint behaves greater seriously than the interior joint throughout the occurrence of earthquake. Many researchers have executed studies on joints using exclusive strategies, substances and brought many repairing strategies to decorate the resisting capacity of joints. From literature, it's been observed that polypropylene and metal scraps have superior many proper houses of concrete. Hence, those fibrous substances may be added in these joints to decorate joint assets. Polypropylene is a plastic polymer and metallic scraps are crafted from top first-rate tough-drawn metal wire to make sure excessive tensile electricity and close tolerances.

The recorded records were plotted to draw hysteresis loop. The result had been compared in various plot like envelope curve, stiffness, strength burn up and ductility. It was observed that performance of fibre specimens in time period of all of the above parameters have been higher than the obvious specimen.

\section{ETABS Software}

Beam column joint is an essential element of a strengthened concrete second resisting body and should be designed and targeted properly, in particular whilst the body is subjected to earthquake loading. Failure of beam column joints in the course of earthquake is governed by means of bond and shear failure mechanism which might be brittle in nature. consequently, a cutting-edge global code offers excessive importance to provide ok anchorage to longitudinal bars and confinement of center concrete in resisting shear a beam column joint has been modeled to a scale of $1 / 5$ throe the prototype and the model has been subjected to cyclic loading to discover its behavior in the course of earthquake. Nonlinear analysis is accomplished in ETABS software.

\subsection{ETABS Ultimate}

Includes all the capabilities of ETABS 2016 ,nonlinear with extra features inclusive of concrete slab layout with publish-tensioning, nonlinear layered shell elements, dynamic analysis making use of nonlinear body and wall hinges, linear and nonlinear direct integration time records analysis, buckling, and the modeling of creep and shrinkage behavior.

\section{Analysis Results}

Fig. 2 shows the modelling of ETABS.

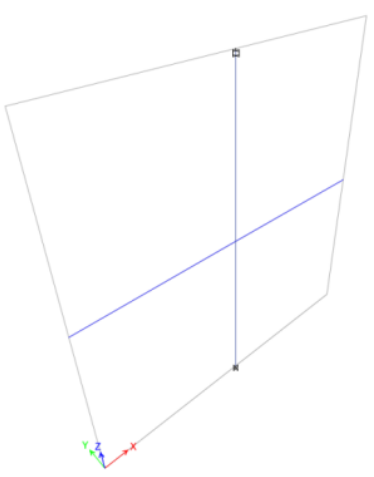

Fig.2: Modelling of ETABS

\subsection{Structure Data}

This area provides model geometry information, including items such as story levels, point coordinates, and element connectivity.

\subsubsection{Storey Data}

Table 1 show the storey data.

\begin{tabular}{|c|c|c|c|c|c|}
\hline Name & $\begin{array}{c}\text { Height } \\
\text { mm }\end{array}$ & $\begin{array}{c}\text { Elevation } \\
\text { mm }\end{array}$ & $\begin{array}{c}\text { Master } \\
\text { Story }\end{array}$ & $\begin{array}{c}\text { Similar } \\
\text { To }\end{array}$ & $\begin{array}{l}\text { Splice } \\
\text { Story }\end{array}$ \\
\hline Story2 & 500 & 1000 & Yes & None & No \\
\hline Storyl & 500 & 500 & No & Story2 & No \\
\hline Base & 0 & 0 & No & None & No \\
\hline
\end{tabular}

\subsection{Loads}

This area provides loading information as applied to the model.

\subsubsection{Load Patterns}

Table 2 shows the load patterns.

Table 2: Load Patterns

\begin{tabular}{|c|c|c|}
\hline Name & Type & $\begin{array}{c}\text { Self Weight } \\
\text { Multiplier }\end{array}$ \\
\hline Dead & Dead & 1 \\
\hline Live & Live & 0 \\
\hline
\end{tabular}

\subsubsection{Load Cases}

Table 3 shows the Load Cases - Summary.

Table 3: Load Cases - Summary

\begin{tabular}{|c|c|}
\hline Name & Type \\
\hline Dead & Linear Static \\
\hline Live & Linear Static \\
\hline
\end{tabular}

\subsection{Analysis Results}

This area provides the analysis results.

\subsubsection{Structure Results}

Table 4 shows the base reactions. 
Table 4: Base reactions

\begin{tabular}{|c|c|c|c|c|c|c|c|c|c|}
\hline $\begin{array}{c}\text { Load } \\
\text { Case/ } \\
\text { Combo }\end{array}$ & $\begin{array}{l}\mathrm{FX} \\
\mathrm{kN}\end{array}$ & $\begin{array}{l}\text { FY } \\
\mathrm{kN}\end{array}$ & $\begin{array}{l}\mathrm{FZ} \\
\mathrm{kN}\end{array}$ & $\begin{array}{c}\mathbf{M X} \\
\mathrm{kN}-\mathrm{m}\end{array}$ & $\begin{array}{c}\mathbf{M Y} \\
\mathrm{kN}-\mathrm{m}\end{array}$ & $\begin{array}{c}\mathrm{MZ} \\
\mathrm{kN}-\mathrm{m}\end{array}$ & $\begin{array}{l}\mathrm{x} \\
\mathrm{m}\end{array}$ & $\begin{array}{l}\mathbf{Y} \\
\mathrm{m}\end{array}$ & $\begin{array}{l}\mathrm{Z} \\
\mathrm{m}\end{array}$ \\
\hline Dead & 0 & 0 & 110.6301 & 0 & -65.315 & 0 & 0 & 0 & 0 \\
\hline Live & 0 & 0 & 0 & 0 & 0 & 0 & 0 & 0 & 0 \\
\hline
\end{tabular}

\subsubsection{Storey Results}

Table 5 shows the storey drifts

Table 5: Story drifts

\begin{tabular}{|c|c|c|c|c|c|c|c|}
\hline Story & $\begin{array}{c}\text { Load } \\
\text { Case/Combo }\end{array}$ & Label & Item & Drift & $\begin{array}{l}\mathrm{X} \\
\mathrm{m}\end{array}$ & $\begin{array}{l}\mathrm{Y} \\
\mathrm{m}\end{array}$ & $\begin{array}{l}\mathrm{Z} \\
\mathrm{m}\end{array}$ \\
\hline Story 2 & Dead & 2 & Max Drift X & 0 & 0.5 & 0 & 1 \\
\hline Story 2 & Dead & 2 & Max Drift Y & 0 & 0.5 & 0 & 1 \\
\hline Story 2 & Live & 2 & Max Drift X & 0 & 0.5 & 0 & 1 \\
\hline Story 2 & Live & 2 & Max Drift Y & 0 & 0.5 & 0 & 1 \\
\hline Storyl & Dead & 2 & Max Drift X & 0 & 0.5 & 0 & 0.5 \\
\hline Storyl & Dead & 2 & Max Drift Y & 0 & 0.5 & 0 & 0.5 \\
\hline Storyl & Live & 2 & Max Drift X & 0 & 0.5 & 0 & 0.5 \\
\hline Storyl & Live & 2 & Max Drift $Y$ & 0 & 0.5 & 0 & 0.5 \\
\hline
\end{tabular}

Table 6 shows the storey forces.

Table 6: Storey forces

Table 6: Storey forces
\begin{tabular}{|c|c|c|c|c|c|c|c|c|}
\hline Story & $\begin{array}{c}\text { Load } \\
\text { Case/Co } \\
\text { mbo }\end{array}$ & Location & $\begin{array}{c}\mathrm{P} \\
\mathrm{kN}\end{array}$ & $\begin{array}{c}\mathrm{VX} \\
\mathrm{kN}\end{array}$ & $\begin{array}{c}\mathrm{VY} \\
\mathrm{kN}\end{array}$ & $\begin{array}{c}\mathrm{T} \\
\mathrm{kN}-\mathrm{m}\end{array}$ & $\begin{array}{c}\mathbf{M X} \\
\mathrm{kN}-\mathrm{m}\end{array}$ & $\begin{array}{c}\mathrm{MY} \\
\mathrm{kN}-\mathrm{m}\end{array}$ \\
\hline Story2 & Dead & Top & -55.315 & 14.0872 & 0 & 0 & 0 & 25.6139 \\
\hline Story2 & Dead & Bottom & -25.415 & 14.0872 & 0 & 0 & 0 & 17.7075 \\
\hline Story2 & Live & Top & 0 & 0 & 0 & 0 & 0 & 0 \\
\hline Story2 & Live & Bottom & 0 & 0 & 0 & 0 & 0 & 0 \\
\hline Storyl & Dead & Top & 25.415 & 14.0872 & 0 & 0 & 0 & - \\
& & & & & & & & 17.7075 \\
\hline Storyl & Dead & Bottom & 55.315 & 14.0872 & 0 & 0 & 0 & - \\
& & & & & & & & 25.6139 \\
\hline Storyl & Live & Top & 0 & 0 & 0 & 0 & 0 & 0 \\
\hline Storyl & Live & Bottom & 0 & 0 & 0 & 0 & 0 & 0 \\
\hline
\end{tabular}

\subsection{Model Results}

Table 7 shows the modal periods and frequencies.

Table 7: Modal periods and frequencies

\begin{tabular}{|c|c|c|c|c|c|}
\hline Case & Mode & $\begin{array}{c}\text { Period } \\
\text { sec }\end{array}$ & $\begin{array}{c}\text { Frequency } \\
\text { cxc/sec }\end{array}$ & $\begin{array}{c}\text { Circular } \\
\text { Frequency } \\
\text { rad/sec }\end{array}$ & $\begin{array}{c}\text { Eigenxalue } \\
\text { rad }^{2} / \text { sec }^{2}\end{array}$ \\
\hline Modal & 1 & 0.104 & 9.639 & 60.5664 & 3668.2843 \\
\hline Modal & 2 & 0.057 & 17.519 & 110.0732 & 12116.1194 \\
\hline Modal & 3 & 0.045 & 22.165 & 139.268 & 19395.5738 \\
\hline Modal & 4 & 0.03 & 33.068 & 207.7714 & 43168.9374 \\
\hline Modal & $\mathbf{5}$ & 0.007 & 148.295 & 931.7649 & 868185.8942 \\
\hline Modal & 6 & 0.006 & 179.796 & 1129.689 & 1276197 \\
\hline
\end{tabular}

Table 8 shows the Modal Participating Mass Ratios (Part 1 of 2)

Table 8: Modal participating mass ratios (part 1 of 2)

\begin{tabular}{|c|c|c|c|c|c|c|c|c|}
\hline Case & Mode & $\begin{array}{c}\text { Period } \\
\text { sec }\end{array}$ & UX & UY & UZ & $\begin{array}{c}\text { Sum } \\
\text { UX }\end{array}$ & $\begin{array}{c}\text { Sum } \\
\text { UY }\end{array}$ & $\begin{array}{c}\text { Sum } \\
\text { UZ }\end{array}$ \\
\hline Modal & 1 & 0.104 & 0 & 0 & 0 & 0 & 0 & 0 \\
\hline Modal & 2 & 0.057 & 0 & 0.7611 & 0 & 0 & 0.7611 & 0 \\
\hline Modal & 3 & 0.045 & 0.9999 & 0 & 0 & 0.9999 & 0.7611 & 0 \\
\hline Modal & 4 & 0.03 & 0 & 0.2389 & 0 & 0.9999 & 1 & 0 \\
\hline Modal & 5 & 0.007 & 0 & 0 & 0 & 0.9999 & 1 & 0 \\
\hline Modal & 6 & 0.006 & 0.0001 & 0 & 0 & 1 & 1 & 0 \\
\hline
\end{tabular}

Table 9 shows the modal participating mass ratios (part 2 of 2)

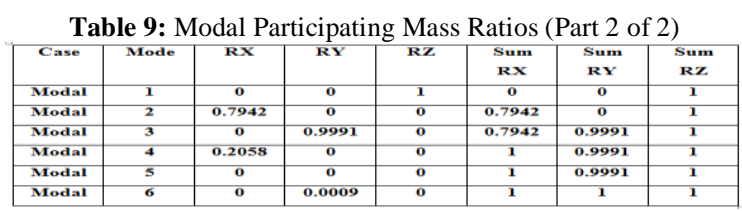

Table 10 shows the modal load participation ratios

Table 10: Modal load participation ratios

\begin{tabular}{|c|c|c|c|c|}
\hline Case & $\begin{array}{c}\text { Item } \\
\text { Type }\end{array}$ & Item & $\begin{array}{c}\text { Static } \\
\%\end{array}$ & $\begin{array}{c}\text { Dynamic } \\
\%\end{array}$ \\
\hline Modal & $\begin{array}{c}\text { Accelerati } \\
\text { on }\end{array}$ & UX & 100 & 100 \\
\hline Modal & $\begin{array}{c}\text { Accelerati } \\
\text { on }\end{array}$ & UY & 100 & 100 \\
\hline Modal & $\begin{array}{c}\text { Accelerati } \\
\text { on }\end{array}$ & UZ & 0 & 0 \\
\hline
\end{tabular}

Table 11 shows the Modal Direction Factors

Table 11: Modal direction factors

\begin{tabular}{|c|c|c|c|c|c|c|}
\hline Case & Mode & $\begin{array}{c}\text { Period } \\
\text { sec }\end{array}$ & UX & UY & UZ & RZ \\
\hline Modal & 1 & 0.104 & 0 & 0 & 0 & 1 \\
\hline Modal & 2 & 0.057 & 0 & 1 & 0 & 0 \\
\hline Modal & 3 & 0.045 & 1 & 0 & 0 & 0 \\
\hline Modal & 4 & 0.03 & 0 & 1 & 0 & 0 \\
\hline Modal & 5 & 0.007 & 0 & 0 & 0 & 0 \\
\hline Modal & 6 & 0.006 & 1 & 0 & 0 & 0 \\
\hline
\end{tabular}

Table 12 shows the Modal Direction Factors

Table 12: Modal direction factors

\begin{tabular}{|c|c|c|c|c|c|c|}
\hline Case & Mode & $\begin{array}{c}\text { Period } \\
\text { sec }\end{array}$ & UX & UY & UZ & RZ \\
\hline Modal & 1 & 0.104 & 0 & 0 & 0 & 1 \\
\hline Modal & 2 & 0.057 & 0 & 1 & 0 & 0 \\
\hline Modal & 3 & 0.045 & 1 & 0 & 0 & 0 \\
\hline Modal & 4 & 0.03 & 0 & 1 & 0 & 0 \\
\hline Modal & 5 & 0.007 & 0 & 0 & 0 & 0 \\
\hline Modal & 6 & 0.006 & 1 & 0 & 0 & 0 \\
\hline
\end{tabular}

Fig. 3 shows the material properties assigning window in ETABS

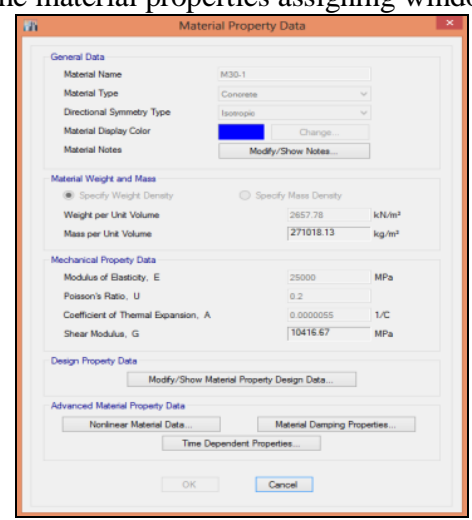

Fig.3: Material properties assigning window in ETABS

Fig.4 shows the deformed shape.

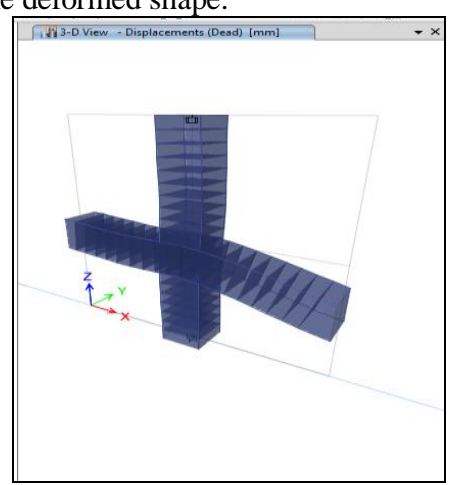

Fig.4: Deformed shape

Fig.5 shows the load applying window. 


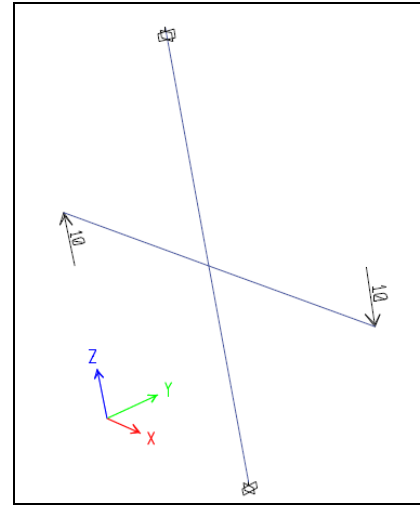

Fig.5: Load applying window

Fig.6 shows the shear force diagram.

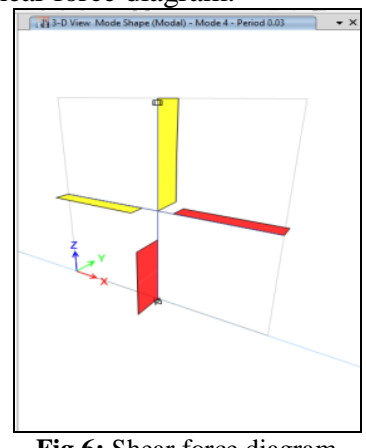

Fig.6: Shear force diagram

\section{Conclusion}

From the project works assessment on the study of the workability and mechanical strength properties of the concrete reinforced with industrialized waste fibers or the recycled fibers which subject to dynamic loading has pointed out the best result while analyzing with ETABS software. Here we use the wastage of steel scrap fiber reinforced concrete (SSRC) and their mechanical properties are found to be increase due to the addition of steel scrap in concrete. The cost - effectiveness also less in our project.

\section{References}

[1] T.Subramani, J.Jayalakshmi, " Analytical Investigation Of Bonded Glass Fibre Reinforced Polymer Sheets With Reinforced Concrete Beam Using Ansys" , International Journal of Application or Innovation in Engineering \& Management (IJAIEM), Volume 4, Issue 5, pp. 105-112, 2015

[2] T.Subramani. , S.Vishnupriya, "Finite Element Analysis of a Natural Fiber (Maize) Composite Beam", International Journal of Modern Engineering Research, Volume. 4, Issue. 6 (Version 1), pp $1-7,2014$,

[3] T.Subramani., R.Senthil Kumar, "Modelling and Analysis of Hybrid Composite Joint Using Fem in ANSYS", International Journal of Modern Engineering Research, Volume 4, Issue 6 (Version 1), pp 41- 46, 2014.

[4] T.Subramani, S.Sharmila, "Prediction of Deflection and Stresses of Laminated Composite Plate with Artificial Neural Network Aid", International Journal of Modern Engineering Research, Volume 4, Issue 6 (Version 1), pp $51-58,2014$.

[5] T.Subramani., S.Sundar, M.Senthilkumar, "Investigation of the Behaviour for Reinforced Concrete Beam Using Non Linear Three Dimensional Finite Elements", International Journal of Modern Engineering Research, Volume. 4, Issue. 6 (Version 2), pp 13 -18, 2014 ,

[6] T.Subramani, A.Arul, "Design And Analysis Of Hybrid Composite Lap Joint Using Fem" International Journal of Engineering Research and Applications, Volume. 4, Issue. 6 (Version 5), pp 289- 295, 2014

[7] T.Subramani., J.Jothi,, M.Kavitha "Earthquake Analysis Of Structure By Base Isolation Technique In SAP", International
Journal of Engineering Research and Applications, Volume. 4, Issue. 6 (Version 5), pp 296 - 305, 2014.

[8] T.Subramani., R.Manivannan.R, M.Kavitha, "Crack Identification In Reinforced Concrete Beams Using Ansys Software" ,International Journal of Engineering Research and Applications, Volume. 4, Issue. 6 (Version 6), pp 133 - 141, 2014.

[9] T.Subramani., Reni Kuruvilla, J.Jayalakshmi., "Nonlinear Analysis Of Reinforced Concrete Column With Fiber Reinforced Polymer Bars" International Journal of Engineering Research and Applications Volume. 4, Issue. 6 (Version 5), pp 306- 316, 2014.

[10] T.Subramani, D.Sakthi Kumar, S.Badrinarayanan. "Fem Modelling And Analysis Of Reinforced Concrete Section With Light Weight Blocks Infill " International Journal of Engineering Research and Applications, Volume. 4, Issue. 6 (Version 6), pp 142 - 149, 2014.

[11] T.Subramani, B.Saravanan., J.Jayalakshmi., "Dynamic Analysis Of Flanged Shear Wall Using Staad Pro", International Journal of Engineering Research and Applications, Volume. 4, Issue. 6 (Version 6), pp 150 - 155, 2014.

[12] T.Subramani, M.Subramani., K.Prasath.,"Analysis Of Three Dimensional Horizontal Reinforced Concrete Curved Beam Using Ansys" International Journal of Engineering Research and Applications, Volume. 4, Issue. 6 (Version 6), pp 156 - 161, 2014.

[13] T.Subramani., K.Bharathi Devi., M.S.Saravanan. , Suboth Analysis Of RC Structures Subject To Vibration By Using Ansys,' International Journal of Engineering Research and Applications Vol. 4, Issue 12(Version 5), pp.45-54, 2014.

[14] T.Subramani., K.Bharathi Devi., M.S.Saravanan., Suboth Thomas, "Analysis Of Seismic Performance Of Rock Block Structures With STAAD Pro International Journal of Engineering Research and Applications Vol. 4, Issue 12(Version 5), pp.55- 68, 2014.

[15] T.Subramani., T.Krishnan., M.S.Saravanan.M , Suboth Thomas, "Finite Element Modeling On Behaviour Of Reinforced Concrete Beam Column Joints Retrofitted With CFRP Sheets Using Ansys" International Journal of Engineering Research and Applications Vol. 4, Issue 12(Version 5), pp.69 -76, 2014

T.Subramani., S.Krishnan., M.S.Saravanan.M, Suboth Thoma "Analysis Of Retrofitting Non-Linear Finite Element Of RCC Beam And Column Using Ansys" International Journal of Engineering Research and Applications ,Vol. 4, Issue 12(Version 5), pp.77-87, 2014.

[17] T.Subramani, J.Jayalakshmi , " Analytical Investigation Of Bonded Glass Fibre Reinforced Polymer Sheets With Reinforced Concrete Beam Using Ansys", International Journal of Application or Innovation in Engineering \& Management (IJAIEM), Volume 4, Issue 5, pp. 105-112, 2015

[18] T.Subramani and M.Kavitha, "Analysis Of Reliability Of Steel Frame Systems With Semi-Rigid Connections Using Numerical Method And Finite Element Analysis", International Journal of Applied Engineering Research (IJAER), Volume 10, Number 38,Special Issues, pp.28240-28246, 2015.

[19] T.Subramani, M.S.Saravanan, “Analysis Of Non Linear Reinforced And Post Tensioned Concrete Beams Using ANSYS", International Journal of Applied Engineering Research (IJAER) International Journal of Applied Engineering Research (IJAER), Volume 10, Number 38 Special Issues, pp.28247-28252, 2015

[20] T.Subramani, K.Balamurugan , " Finite Element Anaylsis Of Composite Element For FRP Reinforced Concrete Slab By Using ANSYS" , International Journal of Application or Innovation in Engineering \& Management (IJAIEM), Volume 5, Issue 5, pp. 076-084, 2016 .

T.Subramani, V.Kanian Poonkundran , " Prefabricated Multistory Structure Exposure To Engineering Seismicity By Using SAP" , International Journal of Application or Innovation in Engineering \& Management (IJAIEM), Volume 5, Issue 5, pp. 123-131, 2016.

[22] T.Subramani, A.Kumaravel, "Analysis Of Polymer Fibre Reinforced Concrete Pavements By Using ANSYS" , International Journal of Application or Innovation in Engineering \& Management (IJAIEM), Volume 5, Issue 5, pp. 132-139, 2016

[23] T.Subramani, R.Praburaj , " Pushover Anaylsis Of Retrofitted Reinforced Concrete Buildings By Using SAP" , International Journal of Application or Innovation in Engineering \& Management (IJAIEM), Volume 5, Issue 5, pp. 140-147, 2016. T.Subramani, M.Senthilkumar, " Finite Element Anaylsis Of RC Beams With Externally Bonded Simcon Laminates By Using ANSYS" , International Journal of Application or Innovation in Engineering \& Management (IJAIEM), Volume 5, Issue 5, pp. $148-155,2016$

[25] T.Subramani, R.Vasanthi, " Earth Quake Resistant Building Using SAP" , International Journal of Application or Innovation in 
Engineering \& Management (IJAIEM), Volume 5, Issue 5, pp. 173-181, 2016 .

[26] T.Subramani, A.Selvam, " Studies On Economical Configuration Of RCC And Prestressed Shell Roofs By Using ANSYS " International Journal of Application or Innovation in Engineering \& Management (IJAIEM), Volume 5, Issue 5, pp. 182-191, 2016.

[27] T.Subramani, A.Anbuchezian , "Experimental Investigation On Flexural Behavior Of Folded Ferro Cement Panels " , International Journal of Application or Innovation in Engineering \& Management (IJAIEM), Volume 6, Issue 3, March 2017 , pp. 045 049 , ISSN 2319 - 4847.

[28] T.Subramani, A. Fizoor Rahman, " An Experimental Study On The Properties Of Pet Fibre Reinforced Concrete " , International Journal of Application or Innovation in Engineering \& Management (IJAIEM), Volume 6, Issue 3, March 2017 , pp. 058 066 , ISSN $2319-4847$

[29] T.Subramani, S.Poongothai, S.Priyanka , " Analytical Study Of T Beam Column Joint Using FEM Software " , International Journal of Emerging Trends \& Technology in Computer Science (IJETTCS), Volume 6, Issue 3, May - June 2017 , pp. 148-156 ISSN 2278-6856

[30] T.Subramani, R.Ganapathy,V.Manoharan, M.Balamurugan, R.Murugesan, " Design And Analysis Of Light Weight Concrete Building Using ETAB With Respect To Dynamic Loading " , International Journal of Emerging Trends \& Technology in Computer Science (IJETTCS), Volume 6, Issue 3, May - June 2017 ,pp. 252-258, ISSN 2278-6856.

[31] T.Subramani, A.Mohammed Ali, R.Karthikeyan, E.Panner Selvan, K.Periyasamy , " Analytical Study Of T-Beam Using ANSYS " International Journal of Emerging Trends \& Technology in Computer Science (IJETTCS), Volume 6, Issue 3, May - June 2017 , pp. 259-266, ISSN 2278-6856.

[32] T.Subramani, V.Kalaivanan, S.Priyaranjithkumar, P.Sasikumar, P.Vinoth Kumar, " Design And Analysis Of Multistorey Building With Respect To Seismic Loads Using ETABS ", International Journal of Emerging Trends \& Technology in Computer Science (IJETTCS), Volume 6, Issue 3, May - June 2017 , pp. 267-274, ISSN 2278-6856. 